\title{
South Carolina's Climate Report Card: The Influence of the EI Niño Southern Oscillation Cold and Warm Event Cycles on South Carolina's Seasonal Precipitation
}

\author{
Hope Mizzell and Jennifer Simmons
}

\begin{abstract}
AUTHORS: S.C. State Climatology Office, S.C. Department of Natural Resources, 1000 Assembly Street, Columbia, South Carolina, 29201, USA.
\end{abstract}

\begin{abstract}
This study was driven by the need to better understand variations in South Carolina's seasonal precipitation. Numerous weather-sensitive sectors such as agriculture and water resource management are impacted by the seasonal variability and distribution of precipitation. Studies have shown that El Niño-Southern Oscillation (ENSO) has varying effects on seasonal temperature and precipitation across the United States.

The purpose of this study was to determine the relative influence of ENSO cold and warm event cycles on interannual variations of South Carolina's seasonal precipitation (19502015). The relationship between seasonal precipitation departures from normal and the average Multivariate ENSO Index was analyzed. Seasonal precipitation totals for each of South Carolina's seven climate divisions and for three key city locations (Greenville-Spartanburg Airport, Columbia Airport, and Charleston Downtown) were examined.

Results from the study indicate that the magnitude, seasonal variation, and consistency of the precipitation response to ENSO vary spatially and from episode to episode. Winter precipitation tends to be enhanced during the warm phase (El Niño) and reduced during the cold phase (La Niña). There is a less consistent signal during fall and no evident connection between ENSO and spring and summer precipitation.
\end{abstract}

\section{INTRODUCTION}

South Carolina has a mild climate and, in normal years, adequate precipitation. While there is no distinct wet or dry season in South Carolina, average precipitation does vary throughout the year (Figure 1). Summer precipitation is normally the greatest, but the most variable, occurring mostly in connection with localized showers, sea breeze convection, and diurnal thunderstorms. Fall is historically the driest season. Any heavy precipitation during this period is likely a result of tropical features, early winter storms, or stalled boundaries. Precipitation during winter and spring occurs mostly in connection with frontal passages. The

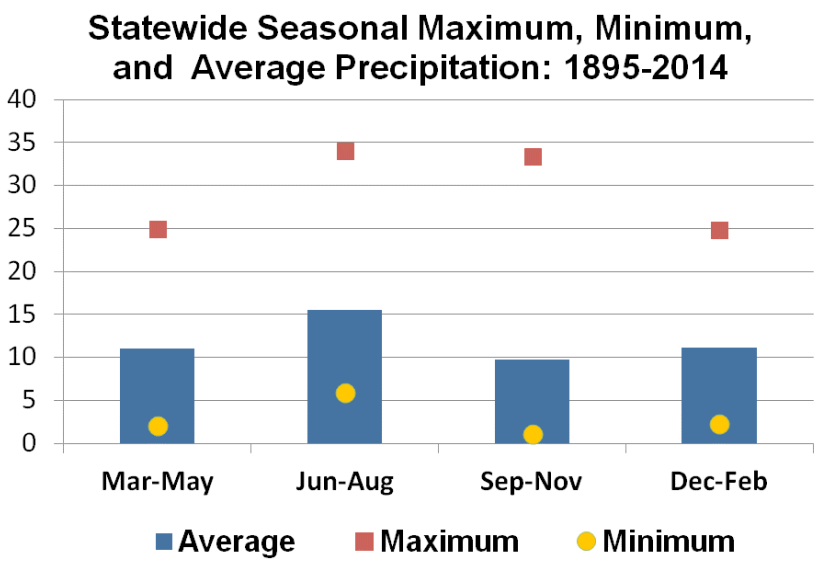

Figure 1. Statewide Seasonal Maximum, Minimum, and Average Precipitation: 1895-2014.

seasons are climatologically defined as winter (DecemberFebruary), spring (March-May), summer (June-August), and fall (September-November).

South Carolina's precipitation varies geographically. Annual precipitation in South Carolina is heaviest in the Northwest and Mountain regions, averaging between 70 to 80 inches at the highest elevations. The driest portion of the state is the central region, where annual totals average between 39 to 42 inches.

South Carolina's seasonal weather varies from localized events to larger-scale, multi-year events. The year-to-year variations in the weather patterns are often associated with changes in wind, pressure, storm tracks, and the jet stream. These weather pattern changes are often linked to large-scale shifts or oscillations of the ocean-atmosphere system such as the El Niño-Southern Oscillation (ENSO) in the Equatorial Pacific (Climate Prediction Center, 2015).

Most research has focused on the relationship between precipitation and ENSO at global and regional scales (Barlow et al., 2001; Dai et al., 1997; Groisman and Easterling, 1994; Ropelewski and Halpert, 1986). While some of this research 
includes South Carolina precipitation, the work is broader in scope and not focused on documenting and detecting localized changes in seasonal precipitation patterns due to fluctuations of the ENSO cycle.

\section{PROJECT OBJECTIVES}

The objectives for this study are: (1) develop a time series of seasonal precipitation (1950-2014) for each of South Carolina's seven climate divisions and three key city locations (Greenville-Spartanburg Airport, Columbia Airport, and Charleston Downtown); (2) utilize the Multivariate ENSO Index to classify each season as Neutral, Strong La Niña, Moderate to Weak La Niña, Moderate to Weak El Niño, or Strong El Niño; and (3) examine how seasonal precipitation in South Carolina responds to the varying strengths of the warm and cold ENSO episodes.

\section{PROJECT BACKGROUND AND DESCRIPTION}

ENSO is an important coupled ocean-atmosphere phenomenon in the equatorial Pacific region. Through complex interactions between the oceans and the atmosphere, the ENSO can directly and indirectly have an impact around the world. El Niño and La Niña represent opposite phases in this naturally occurring climate cycle (Climate Prediction Center, 2015; University Corporation for Atmospheric Research, 2015). They are associated with opposite extremes in sea-surface temperature departures across the central and east-central equatorial Pacific, and with opposite influences on convective precipitation, surface air pressure, and atmospheric circulation. El Niño refers to the above-average sea-surface temperatures that periodically develop across the east-central equatorial Pacific. It represents the warm phase of the ENSO cycle. La Niña refers to the periodic cooling of sea-surface temperatures across the east-central equatorial Pacific. It represents the cold phase of the ENSO cycle. ENSO-neutral refers to those periods when neither El Niño nor La Niña is present. During ENSO-neutral periods, the ocean temperatures, tropical precipitation patterns, and atmospheric winds over the equatorial Pacific Ocean are near the long-term average.

El Niño and La Niña are typically strongest during winter and spring because the equatorial Pacific sea-surface temperatures are normally warmest at this time of the year. However, there is considerable variation in the intensity and duration of each ENSO cycle. Scientists from the National Oceanic and Atmospheric Administration and other agencies use a variety of tools and techniques to monitor and forecast changes in the Pacific Ocean. The Multivariate ENSO Index (MEI) is one method used to monitor the ENSO based on six main variables over the tropical Pacific: sea-level pressure, zonal and meridional components of the surface wind, sea surface temperature, surface air temperature, and total cloud cover fraction of the sky (Wolter and Timlin, 2011). MEI is calculated as the first unrotated Principal Component of all six observed fields combined. Positive MEI values are related to warm phase or El Niño events and negative values with cool phase or La Niña events.

ENSO events have varying effects on temperature and precipitation across the United States. There is research that documents the impact of ENSO in the Southeast U.S. with El Niño typically associated with wet and cool winters and the La Niña typically associated with dry and warm winters (Ropelewski and Halpert 1986; Schmidt et al., 2001). El Nino and La Nina produce extensive yet differing redistributions of precipitation across the tropical Pacific as well as extensive teleconnections that affect synoptic weather patterns extending across the continental United States. Since much of the research is broad in scope or specific to other Southeast states, this project will focus on documenting and detecting localized changes in South Carolina's seasonal precipitation patterns due to fluctuations of the ENSO cycle.

Climate divisional data were utilized for this project. Each U.S. state is subdivided into climatic divisions with boundaries that are delineated partially on climatic conditions, but also reflect county lines, drainage basins, or major crops. The area of each of the U.S. contiguous states has been divided into between one and 10 climate divisions (National Centers for Environmental Information, 2015). South Carolina has seven climate divisions. (Figure 2).

Climate division data is provided on a monthly basis by the National Centers for Environmental Information. The climate divisional dataset consists of monthly average temperature, precipitation, heating/cooling degree days, and various drought indices since 1895 . The data are derived from area-weighted averages of $5 \mathrm{~km}$ by $5 \mathrm{~km}$ grid-point estimates interpolated from station data (Vose et al., 2014). The Global Historical Climatology Network is the source of station data. The number of stations utilized in each month's analysis varies due to station additions, closures, or station removals due to data errors. Despite some weaknesses, the

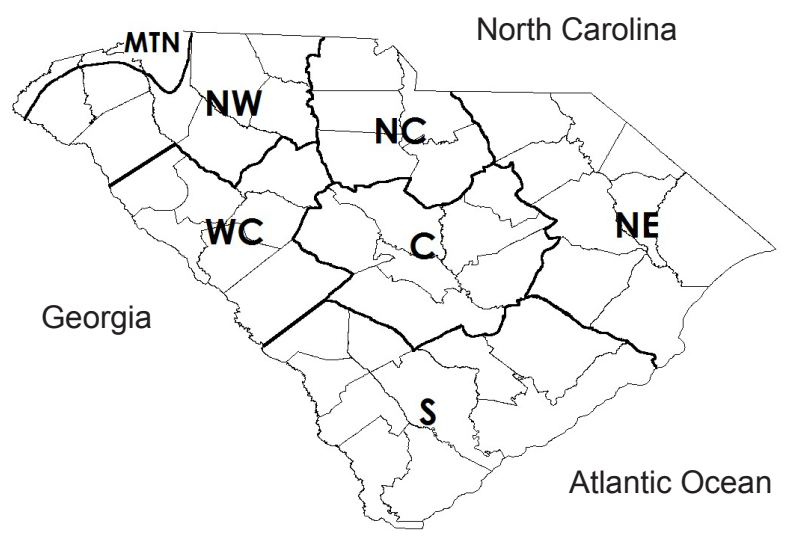

Figure 2. South Carolina Climate Divisions (MTN=Mountains, $\mathrm{NW}=$ Northwest, $\mathrm{NC}=$ North Central, $\mathrm{NE}=$ Northeast, $\mathrm{WC}=$ West Central, $\mathrm{C}=$ Central, $\mathrm{S}=$ Southern). 
divisional dataset has proven to be useful for putting anomalous meso-scale and macroscale weather events into historical perspective (Guttman and Quayle, 1996).

\section{METHODOLOGY}

A time series of seasonal precipitation (1950-2014) for South Carolina's seven climate divisions and three key city locations was developed. Greenville-Spartanburg Airport, Columbia Airport, and Charleston Downtown were selected as the city locations. Greenville-Spartanburg's period of record was shorter, beginning in 1963. Percent of normal precipitation values for each season were computed using a base period of 1901-2000 for each climate division and for each station's period of record. The bimonthly MEI was utilized to classify each season as Neutral, Strong La Niña, Moderate to Weak La Niña, Moderate to Weak El Niño, or Strong El Niño. For each season, the three bimonthly values were averaged (e.g., November/December, December/ January, and January/February for Winter). Once the average seasonal MEI was obtained, values greater than 1.0 were designated as El Niño and less than -1.0 as La Niña events. All values between -1.0 and +1.0 were considered ENSO neutral and discarded. The values greater than 1.0 and less than -1.0 were then separated based on percentiles. Values less than or greater than the 25 th percentile were classified as strong events. Values between the 25 th and 75 th percentiles were considered Moderate to Weak ENSO events.

Seasonal precipitation totals for each of the seven South Carolina climate divisions and for three key city locations (Greenville-Spartanburg Airport, Columbia Airport, and Charleston Dowtown) were examined. Percent of normal precipitation for each season was analyzed and graphed with respect to the MEI ENSO classification. The percent of normal precipitation values were then averaged for all seasons in each ENSO phase and presented by season and by climate division.

\section{RESULTS}

The effect of ENSO on precipitation in South Carolina is not uniform. There appear to be seasonal precipitation differences between upstate, central, and coastal portions of the state. Table 1 displays the seasonal percent of normal precipitation values averaged for each type of ENSO phase. Figures 3 and 4 show the individual winter percent of normal values for each ENSO phase for six of the seven climate divisions. The graph for the Mountain Division was not displayed since the division covers a small geographic area.

The most notable precipitation signal across South Carolina occurs during winter. There is an overall negative winter precipitation anomaly in all seven climate divisions for Moderate/Weak and Strong La Niña events (Table 1). Likewise there is an overall positive winter precipitation anomaly in all seven climate divisions for Strong El Niño events and for six out of the seven climate divisions for Moderate/Weak El Niño events. Another notable result is that there is a $23 \%$ to $56 \%$ increase in precipitation during Strong El Niño winters compared to Strong La Niña winters depending on climate division.

The winter El Niño signal is the highest for the Southern climate division with 39\% higher than average precipitation during Strong El Niño events and 17\% higher than average during Moderate/Weak El Niños. Figures 3 and 4 show all ENSO winters and the percent of normal precipitation that occurred in each climate division. The graphs display the range of percent of normal precipitation for each ENSO phase (driest winter to the wettest). For example, for the Southern climate division (Figure 4), during Strong El Niño winters, the precipitation departures ranged from $1 \%$ below normal to $117 \%$ above normal. Three out of the six Strong El Niño winters received greater than $30 \%$ of normal precipitation.

In order to evaluate whether the precipitation was above, below, or normal during each season, a $+/-30 \%$ of normal criteria was established. Precipitation was considered normal for each season if the average departure from normal was between $+30 \%$ above normal and $-30 \%$ below normal. There appears to be a clear ENSO influence on winter precipitation statewide even though the averages were less for some of the climate divisions. At least 16 out of 19 La Niña winters (Weak to Strong) experienced normal to below normal precipitation for all climate divisions. The only La Niña winters that recorded above normal precipitation were 1961-1962, 1973-1974, and 1974-1975. El Niño's influence on winter precipitation was equally as substantial, but with opposite results as expected. At least 13 out of 15 El Niño (Weak to Strong) winters for all climate divisions experienced normal to above normal precipitation. The only El Niño winters that were dry ( $<-30 \%$ of normal precipitation) were 1979-1980 and 1987-1988.

Results from the key cities reinforced results from the climate divisions. The period of record analyzed for Greenville-Spartanburg is 1963-2014. The study period for Columbia and Charleston is 1950-2014. Charleston experienced an average $47 \%$ increase in winter precipitation during Strong El Niño winters and a 15\% increase during Moderate to Weak El Niño winters. Columbia received an average $27 \%$ increase in winter precipitation during Strong El Niño winters and an 18\% increase during Moderate to Weak El Niño winters. The influence of El Niño on preciptitation in Greenville-Spartanburg was less obvious with only a $17 \%$ average increase during Strong El Niño winters and 9\% average increase during Weak to Moderate El Niño winters. During La Niña winters, average precipitation was reduced by $18 \%$ to $20 \%$ in Charleston, by $6 \%$ to $12 \%$ in GreenvilleSpartanburg, and less than $9 \%$ in Columbia.

The strength of the ENSO did not seem to be a factor in whether or not the signal was consistent. For instance, not all Strong El Niño winters had above normal precipitation nor did all Strong La Niña winters record below normal precipitation. Several Moderate to Weak El Niño winters recorded higher precipitation totals compared to Strong El 
Table 1. Seasonal percent of normal precipitation values averaged for each ENSO phase, 1950-2014. Each season was classified as one of the following ENSO phases: Strong La Niña, Moderate/Weak La Niña, Moderate/Weak El Niño, or Strong El Niño. The seasonal percent of normal precipitation was then averaged for each ENSO phase. The years included in each ENSO phase will vary depending on season. For example, Strong El Niño Winters include 1957-58, 1972-1973, 1982-83, 1991-92, 1997-98 and Strong El Niño Summers include 1965, 1972, 1982, 1983, 1997.

\begin{tabular}{|c|c|c|c|c|}
\hline \multicolumn{5}{|l|}{ Spring } \\
\hline Climate Division & Strong La Nina & $\begin{array}{l}\text { Moderate/Weak } \\
\text { La Nina }\end{array}$ & $\begin{array}{l}\text { Moderate/Weak } \\
\text { El Nino }\end{array}$ & Strong El Nino \\
\hline Mountain & +2.46 & +7.37 & -4.05 & +7.46 \\
\hline Northwest & -3.04 & +6.01 & +4.98 & +9.40 \\
\hline North Central & +1.03 & +2.47 & -5.34 & +4.17 \\
\hline West Central & +2.46 & +7.37 & -4.05 & +7.46 \\
\hline Central & -3.71 & +2.90 & -7.35 & +8.43 \\
\hline Northeast & +2.28 & -0.47 & -5.08 & +14.54 \\
\hline Southern & -1.07 & -1.25 & +3.35 & +14.50 \\
\hline \multicolumn{5}{|l|}{ Summer } \\
\hline Mountain & +11.27 & -9.98 & -10.98 & -8.21 \\
\hline Northwest & -5.87 & -20.41 & -12.43 & -11.51 \\
\hline North Central & +0.02 & -10.22 & -14.41 & -8.09 \\
\hline West Central & +11.27 & -9.98 & -10.98 & -8.21 \\
\hline Central & +5.18 & -4.89 & -8.89 & -2.24 \\
\hline Northeast & +6.76 & -5.29 & -5.83 & -5.66 \\
\hline Southern & +14.89 & -3.32 & -6.61 & -3.06 \\
\hline \multicolumn{5}{|l|}{ Fall } \\
\hline Mountain & +1.52 & -12.01 & +30.95 & +3.49 \\
\hline Northwest & +10.09 & -11.61 & +30.82 & -2.84 \\
\hline North Central & -5.99 & +0.16 & +25.32 & +8.99 \\
\hline West Central & +1.52 & -12.01 & +30.95 & +3.49 \\
\hline Central & -11.21 & -5.50 & +15.90 & +16.10 \\
\hline Northeast & +0.07 & +4.58 & +5.98 & +14.17 \\
\hline Southern & -5.18 & -8.04 & +9.59 & +21.92 \\
\hline \multicolumn{5}{|l|}{ Winter } \\
\hline Mountain & -15.98 & -9.29 & +8.55 & +13.44 \\
\hline Northwest & -17.12 & -11.40 & -0.26 & +6.86 \\
\hline North Central & -17.14 & -12.94 & +3.03 & +16.09 \\
\hline West Central & -15.98 & -9.29 & +8.55 & +13.44 \\
\hline Central & -11.42 & -12.14 & +12.41 & +27.24 \\
\hline Northeast & -12.29 & -16.01 & +12.88 & +30.77 \\
\hline Southern & -16.67 & -16.66 & +17.77 & +39.25 \\
\hline
\end{tabular}



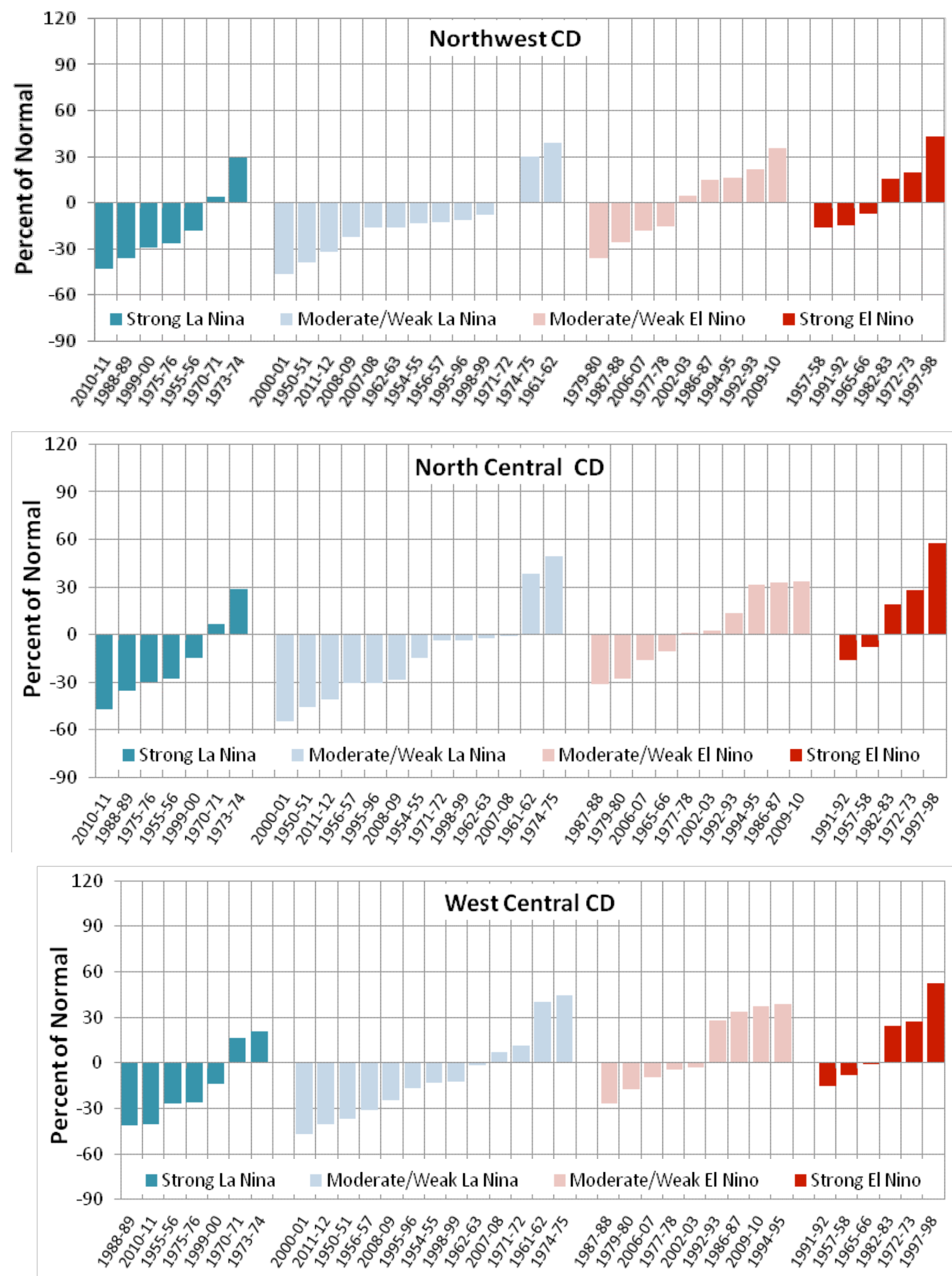

Figure 3. Winter percent of normal precipitation values for each ENSO phase for the Northwest, North Central and West Central Climate Division. Displays the range of percent of normal precipitation for each ENSO phase (driest to wettest). 

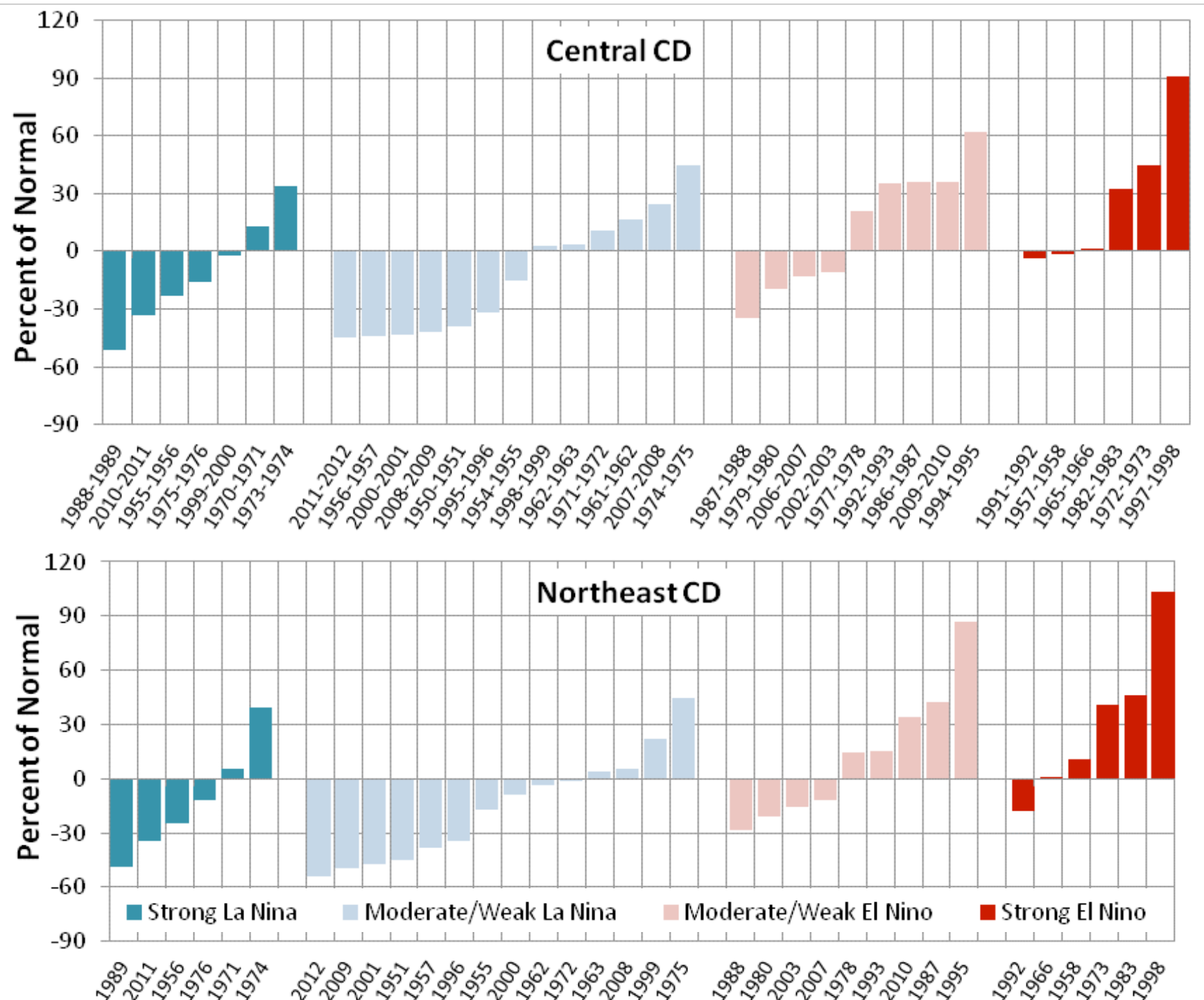

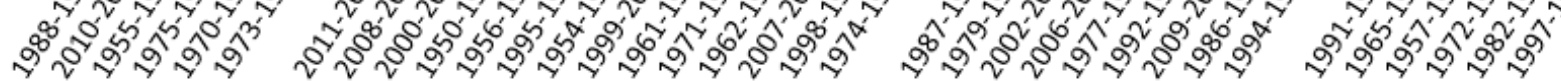
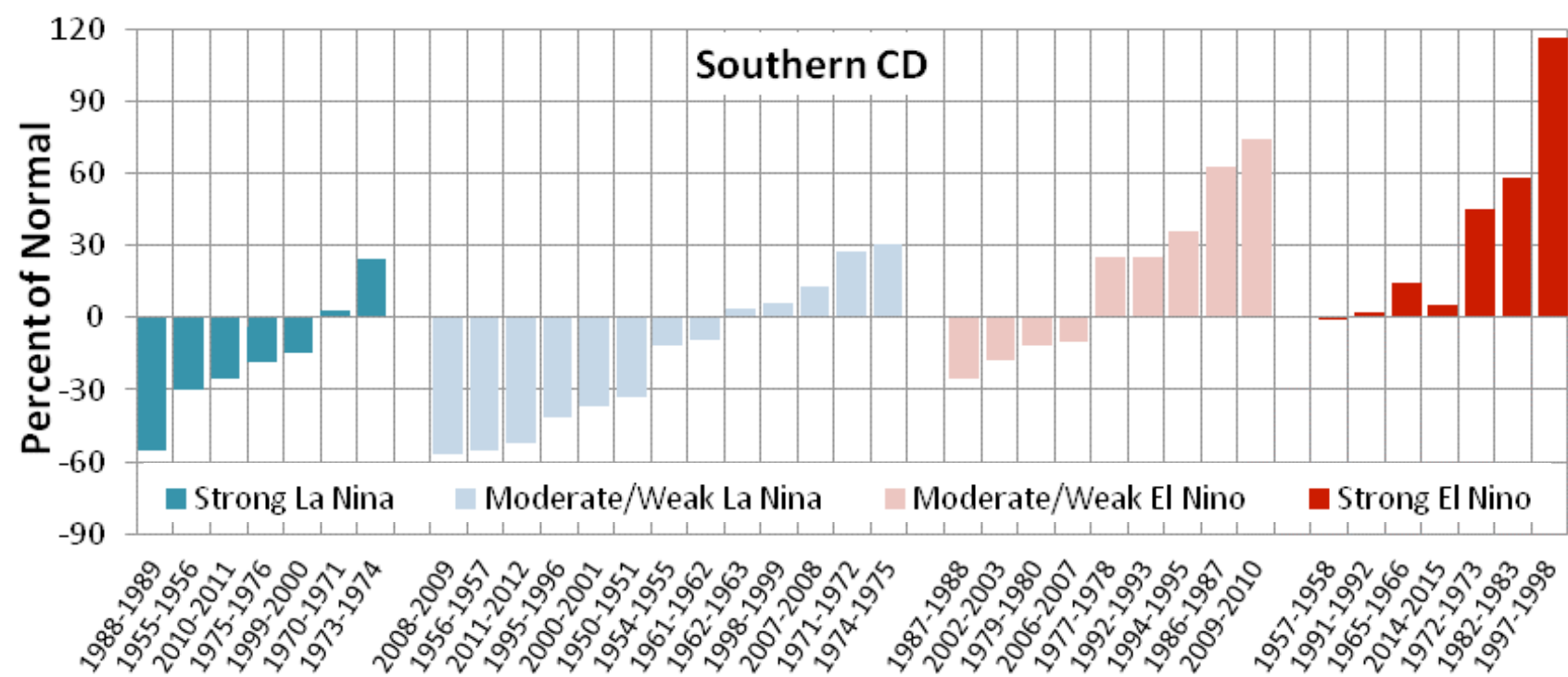

Figure 4. Winter percent of normal precipitation values for each ENSO phase for the Central, Northeast and Southern Climate Division. Displays the range of percent of normal precipitation for each ENSO phase (driest to wettest). 

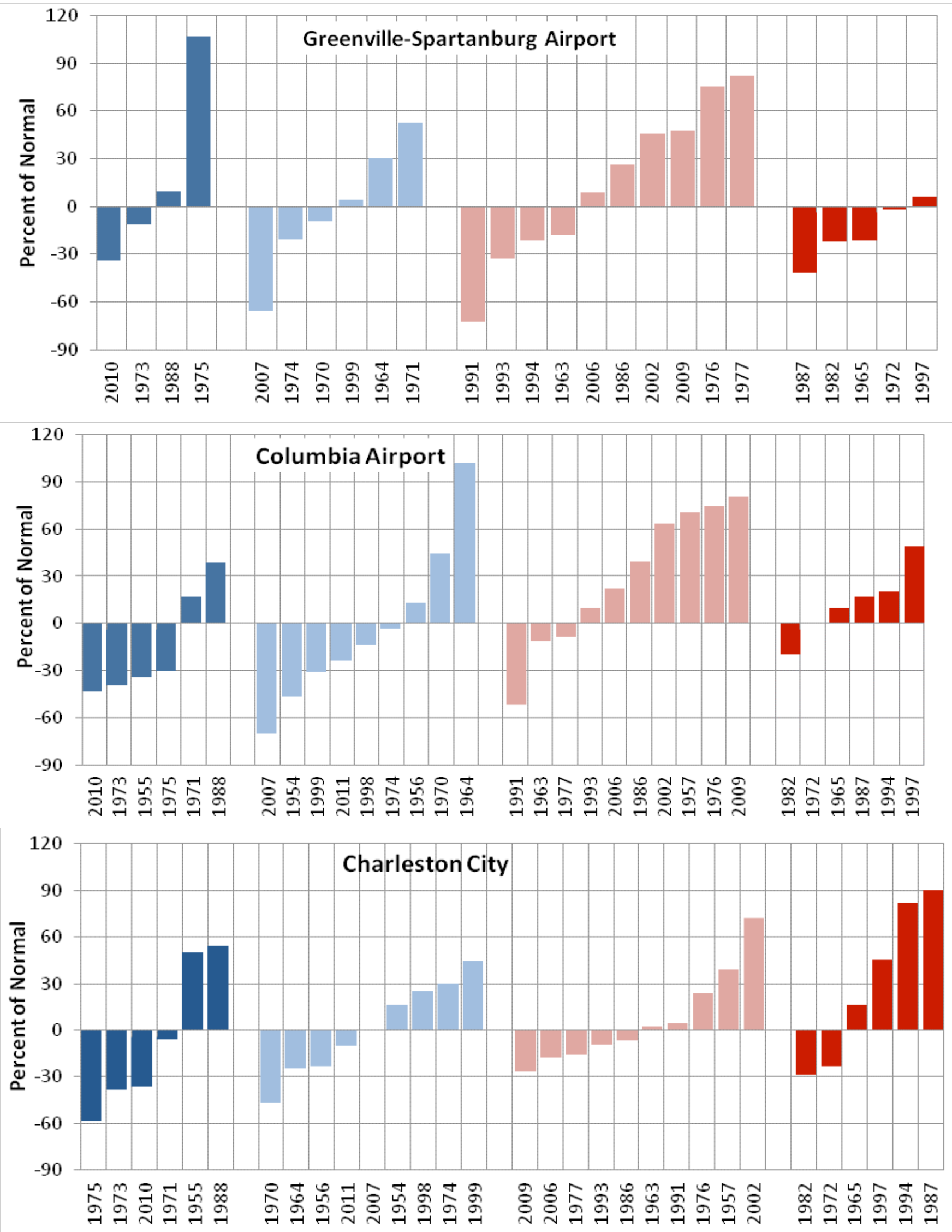

Figure 5. Fall percent of normal precipitation values for each ENSO phase for Greenville-Spartanburg Airport, Columbia Airport and Charleston Downtown. Displays the range of percent of normal precipitation for each ENSO phase (driest to wettest). 


\section{Mizzell, Simmons}

Niño events. Likewise several Moderate to Weak La Niña winters were drier than some of the stronger La Niña winters.

While ENSO's influence on winter precipitation had the most consistent signal, Moderate to Weak El Niño episodes appear to enhance fall precipitation in the Mountain, Northwest, North Central, and West Central climate divisions. The signal was less obvious during Strong El Niño events, except in the Northeast and Southern climate divisions where Strong El Niño episodes had a more apparent signal. Since several of the above normal fall seasonal totals included precipitation from tropical systems, additional investigation is needed to determine the influence of the tropical precipitation on the departures compared to an overall El Niño induced pattern change. La Niña does not appear to have a clear signal on fall season precipitation.

Figure 5 displays the fall ENSO events for GreenvilleSpartanburg, Columbia, and Charleston. All three stations experienced normal to above normal precipitation during most of the fall season Moderate to Weak El Niño events. Strong El Niño events during fall appear to produce normal to above normal precipitation for Columbia and Charleston, but normal to below normal precipitation for Greenville-Spartanburg. La Niña's influence on fall precipitation was not consistent.

\section{CONCLUSIONS}

The magnitude, seasonal deviations, and consistency of the precipitation response to ENSO vary spatially and from episode to episode in South Carolina. Results reveal that ENSO's impact on South Carolina's climate is most notable during winter. The effect of ENSO on precipitation is not uniform. There are seasonal precipitation differences between upstate, central, and coastal portions of the state. There is a negative winter precipitation anomaly during La Niña events and a positive winter precipitation anomaly during El Niño events.

The winter El Niño signal is the highest for the Southern climate division with $39 \%$ higher than average precipitation during Strong El Niño events. Charleston experienced, on average, a $47 \%$ increase in winter precipitation during Strong El Niño winters. La Niña episodes had the opposite impact, reducing winter precipitation with a consistent influence statewide. The strength of the ENSO did not always control the precipitation signal (i.e. not all Strong ENSO events were wetter or drier than Moderate to Weak ENSO Events).

ENSO's influence on fall precipitation is less obvious. El Niño seems to enhance precipitation, but it varies by climate division and by strength of the ENSO event. La Niña does not appear to have a clear signal on fall precipitation. Additional investigation is needed to determine whether precipitation from tropical systems is influencing the departures rather than an overall El Niño-induced pattern change.

El Niño and La Niña are important drivers of the natural variability of regional, U.S. and global climate. ENSO provides some predictable effects to weather patterns. However, every ENSO event differs in magnitude and in duration. Additional research is needed since ENSO may be masked by other weather and climate signals. Single extreme events can alter the overall signal or trend. Future research should expand the investigation to include ENSO's influence on South Carolina temperature. Future analysis should include additional climate patterns that exert important influences on regional climates such as the Pacific Decadal Oscillation and North Atlantic Oscillation.

\section{LITERATURE CITED}

Barlow, M., S. Nigam, and E. H. Berbery, 2001. ENSO, Pacific Decadal Variability, and US Summertime Precipitation, Drought, and Stream flow. Journal of Climate, 14(9): 2105-2128.

Climate Prediction Center, 2015: Frequently Asked Questions about El Niño and La Niña. Retrieved from http:/www.cpc.noaa.gov/products/analysis_monitoring/ ensostuff/ensofaq.shtml\#USimpacts.

Dai, Aiguo, Y. F. Inez, and A. D. Del Genio, 1997. Surface Observed Global Land Precipitation Variations during 1900-88. Journal of Climate, 10(11): 2943-2962.

Groisman, Pavel Y., and D. R. Easterling, 1994. Variability and Trends of Total Precipitation and Snowfall over the United States and Canada. Journal of Climate, 7(1): 184-205.

Guttman, Nathaniel B., and R. G. Quayle, 1996. A Historical Perspective of US Climate Divisions. Bulletin of the American Meteorological Society, 77(2): 293-303.

National Centers for Environmental Information, 2015: History of the United States Climate Divisional Dataset. Retrieved from http://www.ncdc.noaa.gov/monitoringreferences/maps/us-climate-divisions.php.

Ropelewski, C. F., and M. S. Halpert, 1986. North American Precipitation and Temperature Patterns Associated with the El Niño/Southern Oscillation (ENSO). Monthly Weather Review, 114(12): 2352-2362.

Schmidt, Nancy, E. K. Lipp, J. B. Rose, and M. E. Luther, 2001. ENSO Influences on Seasonal Rainfall and River Discharge in Florida. Journal of Climate, 14(4): 615-628.

University Corporation for Atmospheric Research, 2015: El Niño, La Niña \& ENSO FAQ. Retrieved from http://www2. ucar.edu/news/backgrounders/el-nino-la-nina-enso.

Vose, Russell S., S. Applequist, M. Squires, I. Durre, M. J. Menne, C. N. Williams Jr., C. Fenimore, K. Gleason, and D. Arndt, 2014. Improved Historical Temperature and Precipitation Time Series for U.S. Climate Divisions. Journal of Applied Meteorology and Climatology, 53: 1232-1251.

Wolter, Klaus, and M. S. Timlin, 2011. El Niño/Southern Oscillation behavior since 1871 as diagnosed in an extended multivariate ENSO index (MEI.ext). International Journal of Climatology, 31(7): 1074-1087. 